\title{
ANALISIS PELAKSANAAN PENGELOLAAN PENDIDIKAN SEKOLAH DASAR MENGACU STANDAR NASIONAL PENDIDIKAN DI WILAYAH PESISIR
}

\author{
Enditiyas Pratiwi ${ }^{1},{ }^{*}$, Muhsinah Annisa ${ }^{2}$ \\ 1 Jurusan Pendidikan Guru Sekolah dasar Universitas Borneo Tarakan \\ 2 Jurusan Pendidikan Guru Sekolah dasar Universitas Borneo Tarakan
}

\begin{abstract}
Abstrak
Tujuan penelitian ini adalah mendeskripsikan dan menganalisis kesesuaian pengelolaan pendidikan sekolah dasar berdasarkan standar nasional pendidikan di Wilayah Pesisir Tarakan. Penelitian ini menggunakan penelitian kuantitatif deskriptif Subjek penelitian ini adalah 3 Sekolah dasar di wilayah Tarakan bagian pesisir. Hasil yang didapatkan yaitu Aspek pengelolaan pendidikan di sekolah dasar wilayah pesisir diantaranya aspek perencanaan program dan pelaksanaan rencana kerja menunjukkan kesesuaian persentase rata-rata sebesar $92,6 \%$ termasuk dalam kategori sangat baik, terdapat program pengawasan dan evaluasi yang dilaksanakan setiap satu tahun sekali, kepemimpinan sekolah dengan kesesuaian persentase ratarata sebesar 96,15\% dengan kategori sangat baik, sistem informasi manajemen menunjukkan kesesuaian persentase rata-rata sebesar $67 \%$ dengan kategori baik. Persentase kesesuaian pengelolaan sekolah mengacu pada peraturan pemerintah No 19 Tahun 2007 tentang standar pengelolaan pendidikan yaitu untuk daerah pesisir sebesar 92\%. Aspek yang belum sesuai yaitu dalam hal pemenuhan kualitas layanan dan peserta didik, kepemimpinan sekolah yang masih belum optimal serta pengelolaan sistem informasi manajemen masih belum maksimal, penyediaan sistem informasi dan komunikasi belum maksimal dan memadai.
\end{abstract}

\author{
Keywords: \\ Standar Pengelolaan \\ Pendidikan, Sekolah \\ Dasar, Wilayah Pesisir
}

\section{PENDAHULUAN}

Kalimantan utara (Kaltara) adalah provinsi ke-34 dan juga merupakan provinsi termuda di Indonesia sejak diresmikan tanggal 22 April 2013. Kalimantan Utara adalah provinsi yang berbatasan langsung dengan negara tetangga (malaysia) yaitu Bagian Sabah dan Serawak. Sebagai provinsi yang menjadi garda depan Indonesia, tentunya menjadi tantangan tersendiri bagaimana menjadi provinsi yang unggul di segala bidang, salah satunya di bidang pendidikan. Salah satu Kota di Kalimantan Utara adalah Kota Tarakan. Tarakan merupakan satu-satunya kota di wilayah Kalimantan bagian utara. Tarakan memiliki letak dan posisi yang strategis sehingga Tarakan memiliki pelabuhan ekspor impor dan bandara internasional kelas $\mathrm{C}$ yang digunakan sebagai orang sebagai transit dan distribusi barang antar kota dan Negara. Tarakan memiliki daerah peissir. Menurut Bengen dalam Yulianto (2011: 32) wilayah pesisir didefinisikan sebagai wilayah daratan yang berbatasan dengan laut, batas di daratan meliputi daerahdaerah yang tergenang air maupun yang tidak tergenang air yang masih dipengaruhi oleh proses-proses laut seperti pasang surut dan angin laut. Posisi strategis yang dimiliki Tarakan dapat membuat Tarakan lebih berkembang baik dalam bidang ekonomi, sosial dan pendidikan.

Pendidikan merupakan salah satu faktor yang sangat penting dalam membangun peradaban dan kemajuan suatu bangsa. Sebagai kota yang sedang berkembang, Tarakan telah memprioritaskan pendidikan bagi masyarakatnya. Karena, sebagian orang memandang bahwa pendidikan dapat membentuk jati diri seseorang, selain itu pendidikan adalah investasi di masa yang akan datang. Pendidikan merupakan Investasi yang akan dirasakan bukan hanya dalam jangka pendek, akan tetapi dapat dirasakan masyarakat dalam jangka panjang. Banyak daerah maju karena masyarakatnya mengenyam pendidikan dengan baik. Karena pendidikan itu identik dengan perkembangan zaman, dan persaingan ilmu pengetahuan. Oleh karena itu pendidikan salah satu faktor dalam menunjang suatu daerah untuk terus bisa berkembang dan maju. 
Sebagai kota yang menjadi beranda negara Indonesia di bagian Utara, tentunya harus memiliki pendidikan yang berkualitas dan mampu bersinergi di kancah internasional, hal ini diharapkan agar dapat mengurangi perbedaan keadaan antara Tarakan (Indonesia) dan negara tetangga (Malaysia). Posisi strategis yang dimiliki Tarakan seyogiyanya dapat membuat Tarakan lebih berkembang baik dalam bidang ekonomi, sosial dan pendidikan. Salah satu yang harus mendapat perhatian lebih bagi pemerintah Provinsi Kaltara adalah dalam hal pengelolaan pendidikan khususnya pengelolaan pendidikan sekolah dasar.

Pelaksanaan pendidikan akan dapat terlaksana lebih baik lagi jika delapan standar nasional pendidikan telah terimplementasikan di satuan pendidikan masing-masing sekolah agar dapat mencapai tujuan pendidikan nasional seperti yang diamanatkan pada peraturan pemerintah nomor 19 tahun 2005 tentang standar nasional pendidikan. Delapan standar tersebut saling menunjang satu sama lain dalam mencapai tujuan nasional pendidikan, Salah satu aspeknya yaitu standar pengelolaan. Pengelolaan sekolah yang baik diharapkan dapat menunjang keberhasilan pendidikan dan proses pembelajaran. pengelolaan pendidikan yang baik yang meliputi perencanaan program, pelaksanan rencana kerja, pengawasan dan evaluasi, kepemimpinan sekolah, sistem informasi manajemen dan penilaian khusus. Berdasarkan paparan tersebut, perlu adanya kajian mengenai standar pendidik dan tenaga pendidikan di wilayah pesisir Tarakan yang mengacu kepada peraturan pemerintah nomor 19 tahun 2007 tentang standar pengelolaan pendidikan.

\section{METODE PENELITIAN}

Penelitian ini menggunakan penelitian kuantitatif deskriptif dengan pendekatan survey. Subjek penelitian ini 3 Sekolah Dasar Negeri di Tarakan yang terletak di bagian pesisir. Penelitian ini dilakukan pada bulan April - Agustus 2017. Teknik pengambilan data pada penelitian ini adalah dengan observasi, wawancara, dan dokumentasi mengenai pengelolaan pendidikan yang ada di sekolah dasar wilayah pesisir Tarakan. Instrumen penelitian yang digunakan yaitu lembar observasi dan panduan wawancara. Lembar observasi dan panduan wawancara digunakan sebagai acuan untuk memperoleh data mengenai pengelolaan pendidikan di 3 sekolah dasar wilayah pesisir Tarakan. Teknik analisis data pada penelitian ini yaitu dengan mengolah data yang telah dikumpulkan berdasarkan hasil observasi, wawancara, dan dokumentasi, kemudian menghitung persentase kesesuaian antara data yang terdapat disekolah dan peraturan pemerintah No 19 Tahun 2007 tentang standar pengelolaan pendidikan. Selanjutnya data tersebut dideskripsikan dan ditarik kesimpulan mengenai kesesuaian standar pengelolaan pendidikan di 3 sekolah dasar wilayah pesisir berdasarkan peraturan pemerintah No 19 Tahun 2007 tentang standar pengelolaan pendidikan. Penentuan kategori kesesuaian standar pengelolaan pendidikan didasarkan pada tabel berikut.

Tabel 1. Kategori Kesesuaian Standar Pengelolaan Pendidikan

\begin{tabular}{ccc} 
No. & Skor & Kriteria \\
\hline 1. & $0 \%-25 \%$ & kurang baik \\
2. & $26 \%-50 \%$ & cukup baik \\
3. & $51 \%-75 \%$ & baik \\
4. & $76 \%-100 \%$ & sangat baik \\
\hline
\end{tabular}

\section{ANALISIS DAN PEMBAHASAN}

Salah satu bagian dari Standar Nasional pendidikan adalah standar pengelolaan pendidikan. Standar pengelolaan berkaitan dengan perencanaan, pelaksanaan dan pengawasan kegiatan pendidikan pada tingkat satuan pendidikan, kabupaten/kota, provinsi atau nasional agar tercapai efisiensi dan efektivitas penyelenggaraan pendidikan (Peraturan pemerintah nomor 19 tahun 2005 bab I pasal 1 butir 9). Standar pengelolaan pendidikan mengacu pada permen no. 19 Tahun 2007 yang meliputi Perencanaan Program dan pelaksanaan rencana kerja, pengawasan, evaluasi, kepemimpinan sekolah dan sistem informasi manajemen dan penilaian khusus. Pengelolaan sekolah dasar yang diteliti meliputi pengelolaan sekolah dasar di wilayah pesisir Tarakan. 
Perencanaan dan pelaksanaan program sekolah menunjukkan hasil persentase sekolah A sebesar $94,4 \%$, sekolah B sebesar 94,4\%, dan sekolah C sebesar $89 \%$. Hasil rata-rata dari perencanaan program sekolah yaitu sebesar $92,6 \%$ menunjukkan perencanaan dan pelaksanaan program sekolah termasuk dalam kategori sangat baik. Persentase perencanaan dan pelaksanaan program sekolah ditunjukkan pada gambar 1 . berikut.

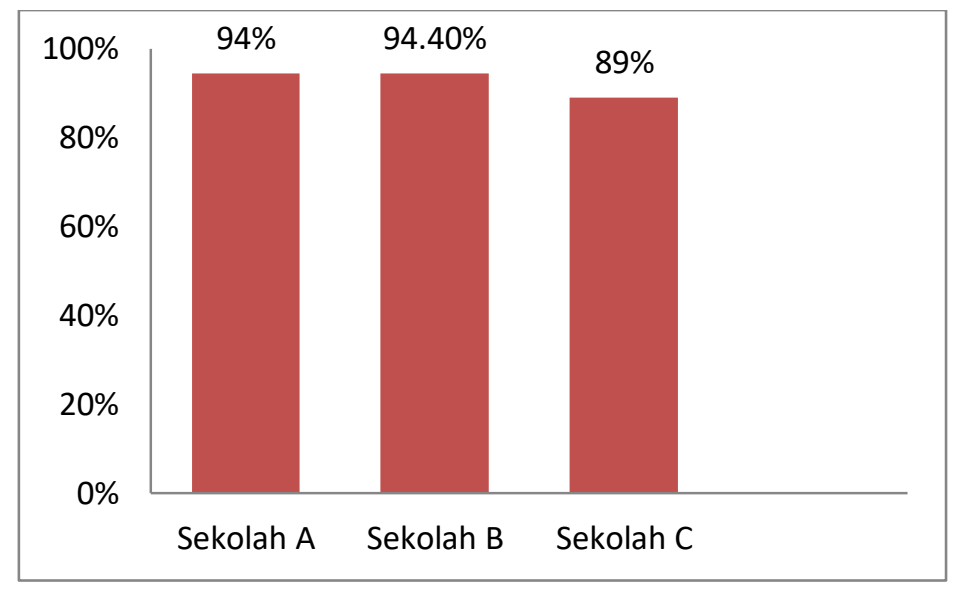

Gambar 1. Kesesuaian perencanaan dan pelaksanaan program sekolah wilayah pesisir Tarakan

Perencanaan dan pelaksanaan program-program pengawasan di 3 sekolah dasar wilayah pesisir Tarakan, yaitu supervisi dilakukan oleh pengawas, kepala sekolah dan guru yang mampu mendampingi, monitoring, evaluasi, pelaporan dan tindak lanjut program hasil pengawasan. Program pengawasan memiliki sasaran kepengawasan dari program yang ada di sekolah adalah meliputi bidang: kurikulum, pembelajaran, penilaian, manajemen sekolah, pembiayaan, ketenagaan, sarana dan prasarana, kesiswaan, serta budaya dan lingkungan sekolah.

Pelaksanaan kegiatan evaluasi diri di 3 sekolah dasar wilayah pesisir dilaksanakan setiap satu tahun sekali guna mengetahui gambaran kinerja sekolah selama satu tahun. Pelaksanaan evaluasi pendidik dan tenaga kependidikan dilaksanakan dengan program penyesuaian penugasan, sekolah juga perlu membuat keseimbangan beban kerja serta program kinerja dan pencapaian prestasi pendidik dan tenaga kependidikan perlu di programkan sehingga pendidik dan tenaga kependidikan yang ada dapat menjalankan tugasnya dengan baik.

Kepemimpinan sekolah menunjukkan hasil persentase sekolah A sebesar 100\%, sekolah B sebesar 88,46\%, dan sekolah C sebesar 100\%. Hasil rata-rata dari kepemimpinan sekolah yaitu sebesar 96,15\% termasuk dalam kategori sangat baik. Persentase kepemimpinan sekolah ditunjukkan pada gambar 2 . berikut.

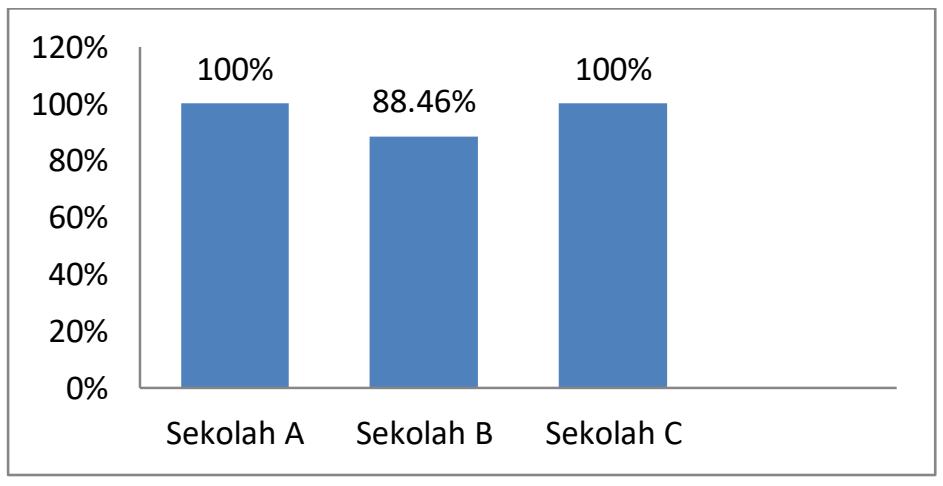

Gambar 2. Kesesuaian kepemimpinan sekolah wilayah pesisir Tarakan

Sistem informasi manajemen sekolah menunjukkan hasil persentase sekolah A sebesar $60 \%$, sekolah B sebesar $80 \%$, dan sekolah C sebesar $60 \%$. Hasil rata-rata dari sistem informasi manajemen sekolah yaitu sebesar $67 \%$ termasuk dalam kategori baik. Persentase sistem informasi manajemen sekolah ditunjukkan pada gambar 3. berikut. 


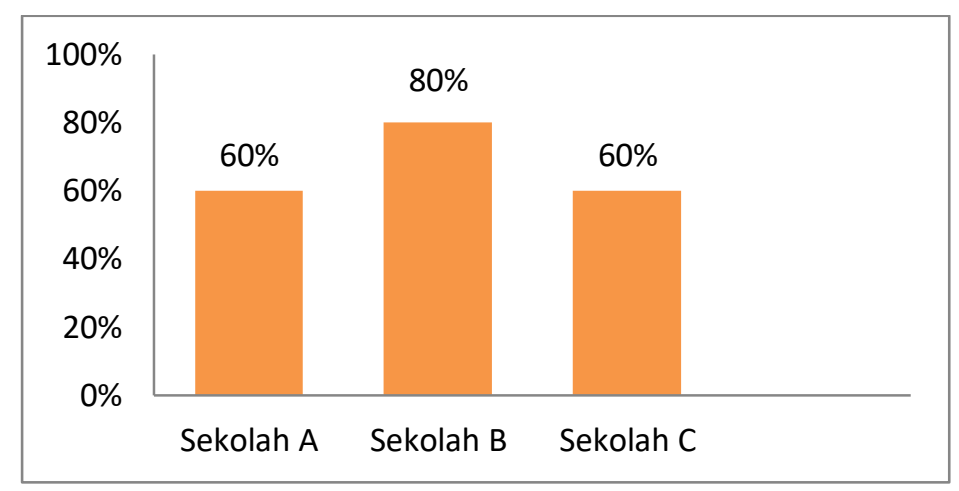

Gambar 3. Kesesuaian sistem informasi manajemen sekolah wilayah pesisir Tarakan

Kesesuaian persentase pengelolaan sekolah dasar di wilayah Tarakan bagian pesisir adalah sebesar 92\%, yang didapatkan dari rata-rata keseluruhan aspek pengelolaan pendidikan di 3 sekolah dasar di wilayah pesisir Tarakan. Berdasarkan aspek pengelolaan sekolah, masih terdapat kriteria yang belum sesuai sebesar $8 \%$, yaitu dalam hal pemenuhan kualitas layanan dan peserta didik, kepemimpinan sekolah yang masih belum optimal serta pengelolaan sistem informasi manajemen masih belum maksimal, penyediaan sistem informasi dan komunikasi belum maksimal dan memadai.

UU No. 32 Tahun 2004 tentang Otonomi Daerah (pasal 13 ayat 1: f) melimpahkan sebagian wewenang pengelolaan pendidikan di daerah kepada pemerintahan daerah. Kebijakan ini memberikan kesempatan kepada daerah mengelola dan mengembangkan sektor pendidikan sesuai potensi dan kondisi masing-masing daerah. Dengan adanya otonomi daerah,maka bagi daerah yag memiliki kemampuan finansial dan SDM yang memadai dapa memacu berkembangnya dunia pendidikan nasional, namun pada pihak lain dapat berdampak semakin mundurnya mutu dan pengelolaan pendidikan di daerah lain. Dengan demikian, dapat berakibat semakin lebarnya kesenjangan pendidikan di antara sesama anak bangsa Menurut Lubis (2013: 10) manajemen pendidikan dalam Standar Nasional Pendidikan menata jenjang pengelolaan pendidikan dalam: standar pengelolaan tingkat satuan pendidikan, standar pengelolaan oleh pemerintah daerah, standar pengelolaan oleh pemerintah (pusat). Pembagian wewenang pengelolaan pendidikan ini seiring dengan kiat desentralisasi pemerintahan yang juga melibatkan pengelolaan pendidikan. Hal yang sama juga diungkapkan Haq (2017) menjelaskan bahwa sistem pendidikan di Indonesia secara nasional mempunyai standar dalam pengelolaannya. Secara umum standar pengelolaan pendidikan dibuat untuk menyeragamkan kualitas manajemen di sekolah. Namun secara khusus perlu untuk dianalisis pada masing-masing poin guna pengembangan kualitas pelayanan pendidikan pada sekolah yang melaksanakannya. Analisis tersebut haruslah mampu menunjang lebih maju untuk pengembangan lembaga pendidikan menjadi lebih profesional dan menyesuaikan dengan kebutuhan masyarakat.

Standar pengelolaan di wilayah pesisir dijabarkan sebagai berikut.

a. Visi sekolah di wilayah pesisir telah memenuhi aspek yaitu mengacu pada visi, misi dan tujuan pendidikan nasional, mencerminkan standar keunggulan dan cita-cita tinggi sekolah, mempertimbangkan potensi dan kondisi sekolah serta lingkungannya, kalimat rumusannya mudah dipahami, jelas dan tidak multi tafsir, dan berorientasi ke masa depan. Visi sekolah juga mengandung lebih dari delapan aspek standar, meliputi standar kompetensi lulusan, isi, proses, penilaian, manajemen, pendidik dan tenaga kependidikan, sarana dan prasarana, pembiayaan, seni dan budaya serta lingkungan. Sekolah mensosialisasikan visi sekolah dengan melibatkan enam unsur yang mencakup semua warga sekolah, komite sekolah, masyarakat sekitar, lembaga-lembaga pemerintah dan dewan pendidikan kota, LSM, serta dengan dunia usaha/industri. Dari hasil tersebut dapat diketahui bahwa penerapan visi sekolah telah berjalan dengan baik dan sesuai dengan standar pengelolaan yang telah ditetapkan.

b. Misi sekolah di wilayah pesisir telah memenuhi aspek yaitu memberi arah dalam mewujudkan visi sekolah, merupakan tujuan yang akan dicapai dalam kurun waktu tertentu, memuat pernyataan umum dan khusus yang berkaitan dengan program sekolah, memberikan keluwesan dan ruang gerak pengembangan sehingga dapat ditinjau secara berkala, dan dirumuskan secara lengkap, jelas, mudah dipahami dan telah disosialisasikan. Namun, masih terdapat kriteria yang belum sesuai dengan aspek misi sekolah, yaitu kualitas layanan peserta didik dan mutu lulusan seperti belum terdapat tenaga pendidik di bidang konseling dan pelacakan alumni masih dalam perencanaan. Dengan kondisi sepertinya sekolah perlu meningkatkan kualitas layanan peserta didik dan mutu lulusan dengan 
memenuhi tenaga pendidik yanga ahli di bidang bimbingan konseling dan segera merencanakan pelacakan alumni sehingga sekolah dapat mengetahui mutu lulusan dari sekolahnya.

c. Tujuan sekolah terdiri dari tujuan dua tahunan dan satu tahunan yang telah memenuhi aspek yaitu mengacu pada visi dan misi, menggambarkan tingkat kualitas yang dapat dicapai dalam jangka menengah (empat tahunan), mengacu pada Standar Kompetensi Lulusan (SKL), rumusan rencana kerja jangka menengah dapat diukur ketercapaiannya) serta telah disosialisasikan dan mengandung lebih dari delapan standar yaitu aspek kompetensi lulusan, isi, proses, penilaian, manajemen, pendidik dan tenaga kependidikan, sarana dan prasarana, pembiayaan, seni dan budaya serta lingkungan. Melihat kondisi ini, dapat dikatakan bahwa tujuan sekolah dua tahunan maupun satu tahunan berjalan dengan baik dan sesuai dengan standar pengelolaan.

d. Rencana Kerja Sekolah (RKS) atau rencana kerja empat tahunan di wilayah pesisir telah memenuhi aspek yaitu adanya rencana kerja jangka menengah untuk mendukung pencapaian tujuan jangka empat tahunan, rumusan rencana kerja jangka menengah dapat diukur ketercapaiannya, adanya rencana kerja tahunan dalam bentuk Rencana Kegiatan dan Anggaran Sekolah (RKAS), rumusan rencana kerja tahunan dapat diukur ketercapaiannya. Rencana Kerja Sekolah (RKS) mengandung lebih dari delapan standar yaitu aspek kompetensi lulusan, isi, proses, penilaian, manajemen, pendidik dan tenaga kependidikan, sarana dan prasarana, pembiayaan, seni dan budaya serta lingkungan. Rencana Kerja Sekolah (RKS) dan Rencana Kegiatan dan Anggaran Sekolah (RKAS) juga telah disosialisasikan kepada warga sekolah, komite sekolah, masyarakat, lembaga-lembaga pemerintah kota dan dewan pendidikan kota, LSM, serta dunia usaha seperti perusahaan. Sekolah kedepannya perlu meningkatkan lagi kinerja dalam menyusun Rencana Kerja Sekolah (RKS) dan Rencana Kegiatan dan Anggaran Sekolah (RKAS) sehingga dapat mengetahui peningkatan mutu sekolah dengan tepat.

e. Pelaksanaan kegiatan kesiswaan di wilayah pesisir dimana sekolah telah merencanakan dan melaksanakan seleksi penerimaan siswa baru secara offline dengan melihat umur siswa tersebut, sekolah memberikan layanan konseling melalui guru kelas karena belum terdapat guru bimbingan konseling maka sekolah sebaiknya mengadakan tenaga pendidik di bidang bimbingan konseling, melaksanakan kegiatan ekstra dan kokulikuler, melakukan pembinaan prestasi unggulan, melakukan pelacakan terhadap alumni, dan melakukan pembinaan prestasi unggulan dengan pemberian penghargaan dari sekolah. Melihat kondisi ini, sekolah perlu meningkatkan kualitas kegiatan kesiswaan dengan pengadaan kegiatan-kegiata akademik maupun non akademik bagi siswa dan memberikan penghargaan bagi siswa bersangkutan

f. Pelaksanaan kegiatan pendayagunaan pendidik dan tenaga kependidikan di wilayah pesisir dilaksanakan dengan melakukan pembagian tugas bagi guru kelas, dalam menentukan sistem penghargaan maka sekolah sebaiknya membuat sistem penghargaan apa yang akan diberikan dan mengembangkan profesi melalui kegiatan pelatihan.

g. Pengelolaan sarana dan prasarana dilaksanakan sesuai dengan standar pengelolaan yang telah ditetapkan, namun sarana dan prasarana yang terdapat di sekolah masih ada yang kurang memadai dan sekolah perlu mengadakan pemeliharaan sarana dan prasarana sekolah guna menunjang proses pendidikan di sekolah.

h. Pelaksanaan kegiatan evaluasi diri di wilayah pesisir dilaksanakan setiap satu tahun sekali guna mengetahui gambaran kinerja sekolah selama satu tahun.

i. Pelaksanaan evaluasi pendidik dan tenaga kependidikan dilaksanakan dengan program penyesuaian penugasan, sekolah juga perlu membuat keseimbangan beban kerja serta program kinerja dan pencapaian prestasi pendidik dan tenaga kependidikan perlu di programkan sehingga pendidik dan tenaga kependidikan yang ada dapat menjalankan tugasnya dengan baik.

j. Deskripsi program pengawasan di wilayah pesisir, dimana sekolah melaksanakan program supervisi yang dilakukan oleh pengawas, kepala sekolah dan guru yang dianggap dapat mendampingi dalam program supervisi. Kemudian dilanjutkan dengan monitoring, evaluasi, pelaporan, dan tindak lanjut yang perlu dilakukan sekolah dapat berupa pembinaan langsung pada pendidik atau tenaga kependidikan yang telah di supervisi.

k. Kepemimpinan kepala sekolah telah memenuhi aspek yaitu kualifikasi minimal, usia maksimal, pengalaman mengajar minimal, pangkat minimal, status guru (guru SD), kepemilikan sertifikat pendidik dan sertifikat kepala sekolah, kompetensi kepribadian, kompetensi manajerial, kompetensi kewirausahaan, kompetensi supervisi, kompetensi sosial dan jumlah minimal wakil kepala sekolah, kriteria pengangkatan wakil kepala sekolah serta kemampuan serta keterampilan yang dimiliki. Namun masih terdapat aspek yang belum sesuai yaitu kemampuan wakil kepala sekolah yang masih kurang maksimal dan belum menguasai keterampilan secara maksimal maka sekolah perlu meingkatkan kemampuan dan keterampilan wakil kepala sekolah melalui kegiatan pelatihan, dengan demikian dapat menghasilkan tenaga yang profesional. 
1. Sistem informasi manajemen telah memenuhi aspek yaitu kepemilikan sistem informasi manajemen yang mendukung administrasi pendidikan di sekolah, pengelolaan sistem informasi manajemen namun belum terlaksana secara maksimal, penyediaan fasilitas informasi namun belum terpenuhi secara maksimal, pelaporan data informasi secara berkala dan berkesinambungan serta efektifitas dan efisiensi komunikasi antar warga sekolah di lingkungan sekolah sudah berjalan namun belum maksimal. Melihat kondisi ini, maka sekiranya sekolah perlu meningkatkan kualitas sistem informasi manajemen dengan melakukan pengelolaan, penyediaan, dan pelaporan secara maksimal serta meningkatkan komunikasi antar warga sekolah seperti sering mengadakan pertemuan yang melibatkan seluruh warga sekolah.

Berdasarkan paparan tersebut, secara garis besar, pengelolaan pendidikan di wilayah pesisir Tarakan berada dalam kategori sangat baik, yaitu kesesuaian pengelolaan sekolah berdasarkan permendiknas no 19 Tahun 2007 yaitu sebesar 92\%. Aspek yang belum sesuai yaitu dalam hal pemenuhan kualitas layanan dan peserta didik, kepemimpinan sekolah yang masih belum optimal serta pengelolaan sistem informasi manajemen masih belum maksimal, penyediaan sistem informasi dan komunikasi belum maksimal dan memadai.

Penelitian mengenai pengelolaan pendidikan di sekolah dasar juga dilakukan oleh Rahayu (2015: 62) yang menunjukkan bahwa Pelaksanaan pengelolaan pendidikan di Sekolah Dasar di Kecamatan Ngemplak telah memenuhi standar pengelolaan pendidikan mengacu pada permendiknas no 19 Tahun 2007. Pelaksanaan pengelolaan pendidikan perlu dilaksanakan dengan baik demi tercapainya tujuan pendidikan nasional.

\section{KESIMPULAN}

Aspek pengelolaan sekolah dasar sebanyak 49 aspek, diantaranya aspek perencanaan program (Visi,misi, tujuan dan rencana kerja sekolah), pelaksanaan rencana kerja (Pedoman sekolah, Struktur organisasi,pelaksanaan kegiatan sekolah, bidang kesiswaan,kurikulum dan kegiatan pembelajaran, bidang pendidik dan tenaga kependidikan, bidang sarana prasarana, bidang keuangan dan pembiayaan, budaya dan lingkungan sekolah serta peran serta masyarakat) Pengawasan dan evaluasi, kepemimpinan sekolah, sistem informasi manajemen dan penilaian khusus. Persentase kesesuaian pengelolaan sekolah mengacu pada peraturan pemerintah No 19 Tahun 2007 tentang standar pengelolaan pendidikan yaitu untuk daerah pesisir sebesar $92 \%$. Aspek yang belum sesuai yaitu yaitu dalam hal pemenuhan kualitas layanan dan peserta didik, kepemimpinan sekolah yang masih belum optimal serta pengelolaan sistem informasi manajemen masih belum maksimal, penyediaan sistem informasi dan komunikasi belum maksimal dan memadai.

Untuk Dinas Pendidikan/Pemerintah/Instansi terkait sebaiknya dapat melakukan pemantauan terhadap pengelolaan pendidikan yang ada di setiap daerah masing-masing khususnya di Sekolah Dasar, sehingga pengelolaan di Sekolah Dasar dapat berjalan sesuai dengan Permendiknas RI Nomor 19 Tahun 2007. Selain itu untuk pihak sekolah agar dapat melaksanakan pengelolaan pendidikan sesuai dengan Permendiknas RI Nomor 19 Tahun 2007, sehingga sekolah dapat melakukan perbaikan dan penyempurnaan dalam pengelolaan pendidikan di sekolah.

\section{DAFTAR PUSTAKA}

Dahuri R, Rais Y, Putra SG, Sitepu, M.J. 2011. Pengelolaan Sumber daya Wilayah Pesisir dan Lautan Secara Terpadu. Jakarta: PT. Pradnya Paramita.

Depdiknas. 2007. Peraturan Menteri Nomor 19 Tahun 2007 Tentang Standar Pengelolaan Pendidikan.

Haq, Muhammad Faishal. 2017. Analisis Standar Pengelolaan Pendidikan Dasar dan Menengah. STAIMA AlHikam Malang. Vol. 1, No. 1.

Lubis, Asri. 2013. Pelaksanaan Standar Nasional Dalam Dunia Pendidikan. Universitas Negeri Medan.

Prabowo, Budi Setiyo. 2012. Pelaksanaan Standar Pengelolaan Pendidikan di SMP Negeri 3 Godean. Universitas Negeri Yogyakarta.

Peraturan Menteri Nomor 19 Tahun 2005 Tentang Standar Nasional Pendidikan.

Rahayu, Mugi. 2015. Pelaksanaan Standar Pengelolaan Pendidikan di Sekolah Dasar Kecamatan Ngemplak Kabupaten Sleman. Jurnal Penelitian Ilmu Pendidikan. Vol. 8, No. 1. 
Undang-undang Republik Indonesia Nomor 32 Tahun 2004 tentang Pemerintah Daerah

Undang-undang Republik Indonesia Nomor 20 Tahun 2003 tentang Sistem Pendidikan Nasional. Yulianto. 2011. Perlindungan Dan Pengelolaan Lingkungan Di Kawasan Pesisir Dan Pulau-Pulau Kecil.Universitas Jenderal Soedirman. Purwokerto. 